\title{
STUDI ANALISIS PENGEMBANGAN E-MODUL IPA BERBASIS INKUIRI TERBIMBING DENGAN SUMBER BELAJAR POTENSI LOKAL TERHADAP KEMAMPUAN LITERASI SAINS
}

\author{
Lilis Eka Herdiana $^{1}$, Widha Sunarno ${ }^{2}$ dan Meti Indrowati ${ }^{3}$ \\ ${ }^{1}$ Program Studi Magister Pendidikan Sains, FKIP, Universitas Sebelas Maret \\ Surakarta, 57126, Indonesia \\ Email: ${ }^{1}$ herdianalilis@ student.uns.ac.id; ${ }^{2}$ widhasunarno@staff.uns.ac.id; ${ }^{3}$ metiindrowati@ staff.uns.ac.id
}

Diajukan: 3 Agustus 2021; Diterima: 20 September 2021; Diterbitkan: 30 Oktober 2021

\begin{abstract}
Abstrak: Penelitian ini merupakan studi analisis terkait e-modul (elektroknik modul) berbasis inkuiri terbimbing yang memanfaatkan potensi lokal untuk meningkatkan kemampuan literasi sains siswa. Penelitian ini merupakan tahap awal menganalisis (analysis) yang termasuk dalam model ADDIE. Instrumen yang digunakan dalam penelitian ini adalah kuesioner yang diisi online melalui link google form oleh guru dan siswa di beberapa sekolah di Kabupaten Ponorogo. Data yang didapatkan dianalisis menggunakan analisis deskriptif kualitatif. Hasil menunjukkan bahwa 93\% responden menyatakan perlu dan setuju apabila dilakukan pengembangan elektronik modul (e-modul) IPA berbasis inkuiri terbimbing dengan memanfaatkan sumber belajar potensi lokal untuk meningkatkan literasi sains siswa. Hasil studi analisis digunakan untuk rancangan pengembangan e-modul IPA berbasis inkuiri terbimbing dengan memanfaatkan sumber belajar potensi lokal Kabupaten Ponorogo, yaitu: Telaga Ngebel.
\end{abstract}

Kata Kunci: e-modul, inkuiri terbimbing, potensi lokal, literasi sains

Abstract: This research is an analytical study related to guided inquiry-based e-modules (electronic modules) that utilize local potential to improve students' scientific literacy skills. This research is an early stage of analyzing (analysis) which is included in the ADDIE model. The instrument used in this study was a questionnaire filled out online via a google form link by teachers and students in several schools in Ponorogo Regency. The data obtained were analyzed using qualitative descriptive analysis. The results showed that $93 \%$ of respondents stated it was necessary and agreed to develop an electronic module (e-module) based on guided inquiry by utilizing local potential learning resources to improve students' scientific literacy. The results of the analytical study used to design the development of a guided inquiry-based science e-module by utilizing local potential learning resources in Ponorogo Regency, namely: Telaga Ngebel.

Keywords: e-module, guided inquiry, local potential, scientific literacy

\section{Pendahuluan}

Perkembangan ilmu dan teknologi sangat pesat hingga mempengaruhi berbagai bidang termasuk bidang pendidikan. Guru harus pandai melakukan adaptasi dalam melakukan pembelajaran dengan memadukan teknologi baik dalam proses pembelajaran ataupun bahan ajar. Melalui perkembangan ilmu dan teknologi pembelajaran saat ini memungkinkan siswa untuk melakukan pembelajaran mandiri secara jarak jauh. Guru harus mampu menguasai berbagai bahan ajar berbasis teknologi agar siswa mampu dengan mudah menerima ilmu yang disampaikan. Oleh karena itu dibutuhkan bahan ajar berupa elektronik modul yang memfasilitasi kegiatan belajar siswa secara mandiri sesuai dengan kemampuan masing-masing (Nastiti \& 'Abdu, 2020).

E-modul merupakan suatu sajian materi yang dibuat sistematis untuk mempermudah siswa belajar mandiri. Berbagai kegiatan pembelajaran yang tedapat di dalam e-modul dapat terhubung dengan link yang mempermudah guru dan siswa dalam menggunakan. E-modul juga harus diisi dengan video yang berkaitan dengan pembelajaran, animasi-animasi, gambar, ataupun audio agar dapat memberi siswa pengalaman belajar, memotivasi, dan menarik minatnya (Kemendikbud, 2017). E-modul merupakan bahan ajar yang dikemas secara elektronik. E-modul dapat diakses di komputer ataupun handphone secara utuh dan sistematis, didesain untuk membantu siswa menguasai 
materi termasuk dalam bidang Ilmu pengetahuan IPA (IPA).

Ilmu pengetahan alam (IPA) merupakan pembelajaran yang berkaitan makhluk hidup ataupun tak hidup dan lingkungan sekitar (Kristyowati \& Purwanto, 2019). Hakikat IPA berupa produk, proses, sikap dan aplikasi. IPA sebagai produk berupa berbagai konsep, prinsip, hukum, dan fakta-fakta yang ada. IPA sebagai proses berupa prosedur ilmiah yang dilakukan untuk mencapai sesuatu. IPA sebagai sikap berupa kemampuan yang diperoleh saat prosedur ilmiah, bisa berupa teliti, hati-hati, motivasi tinggi, berpikir logis, dll. Sains sebagai aplikasi berupa kemampuan untuk memanfaatkan ilmu yang diperoleh untuk kehidupan sehari-hari (Kristyowati \& Purwanto, 2019; Tursinawati, 2016).

E-modul dalam pembelajaran IPA lebih mudah digunakan untuk kegiatan belajar apabila terintegrasi dengan sebuah model pembelajaran. Integrasi tersebut dapat mempermudah siswa aktif melakukan kegiatan pembelajaran yang terstruktur sesuai sintaks pembelajaran. Salah satu model pembelajaran yang dapat diintegrasikan ke dalam e-modul IPA adalah inkuiri terbimbing.

Kata inkuiri berasal dari bahasa Inggris inkuiry berarti pemeriksaan atau penyelidikan. Model pembelajaran inkuiri adalah rangkaian kegiatan pembelajaran yang fokus pada proses berpikir secara kritis dan analitis untuk mencari dan menemukan sendiri jawaban dari suatu masalah yang dipertanyakan. Model pembelajaran inkuiri adalah model pembelajaran yang menyiapkan siswa dalam situasi untuk melaksanakan eksperimen sendiri. Siswa didorong untuk memperoleh pengetahuan, kemampuan, dan sikap baru melalui prosedur ilmiah. Eksplorasi fenomena, mengajukan pertanyaan, mencari jawabannya sendiri serta menghubungkan penemuan yang satu dengan penemuan lain (Lee, 2011).

Inkuiri terbimbing merupakan pembelajaran yang mengharapkan siswa mampu mengkonstruk pengetahuan yang dimiliki melalui proses observasi atau identifikasi. Siswa dapat menumbuhkan keterampilan ilmiah dengan sedikit bantuan guru (Anggareni et al., 2013). Pembelajaran inkuiri terbimbing mengajarkan siswa menjadi ilmuan. Siswa dibantu guru dalam melakukan eksperimen sendiri melalui tahapan yang tepat (Fa'idah et al., 2019). Tujuan utama dari pembelajaran inkuiri terbimbing yaitu memangun kemampuan berpikir yang sistematis, logis, dan juga kritis. Siswa bukan sekadar menguasai materi pembelajaran tetapi juga memiliki kecakapan menggunakan kemampuan yang dimiliki (Lee, 2011)

Pembelajaran IPA ditujukan untuk mengenali lingkungan dan alam sekitarnya, serta mengetahui berbagai potensi alam nusantara (Permendikbud, 2016). Guru bisa memperhatikan berbagai potensi lokal yang terdapat di sekitar sekolah sebagai sumber belajar. Sumber belajar adalah sesuatu yang bisa dimanfaatkan oleh guru dan siswa untuk kegiatan belajar agar pembelajaran yang dilakukan efektif, efisien, mudah dan menyenangkan (Abdullah, 2012). Sumber belajar yang memanfaatkan potensi lokal wilayah dapat dikemas dalam e-modul IPA yang didesain untuk mencapai tujuan pembelajaran.

Kearifan lokal/potensi lokal yaitu kemampuan/daya/kekuatan yang dimiliki oleh suatu daerah/tempat yang dapat menghasilkan manfaat ataupun keuntungan. Potensi lokal merpakan suatu sumber daya yang terdapat di suatu wilayah. Dalam setiap wilayah pasti memiliki potensi lokalnya masing-masing, misalnya tempat seperti hutan, gunung, danau, rawa atau bangunan seperti candi, tanaman yang dimanfaatkan sebagai bahan makanan atau obat-obatan, proses mitigasi bencana, dll. (Rusilowati et al., 2016). Potensi wilayah lingkungan sekitar sangat berpotensi untuk dapat mengembangkan kemampuan literasi siswa (Fuadi et al., 2020).

Pembelajaran Era Sosiety 5.0 menuntut siswa untuk memiliki berbagai kemampuan abad 21, salah satunya yaitu kemampuan literasi sains. Tetapi berdasarkan hasil PISA (Program for International Assesment of Student) dan beberapa penelitian menunjukkan hasil bahwa kemampuan literasi sains siswa tergolong rendah. Hasil data PISA menyatakan kemampuan literasi sains siswa di Indonesia berada di peringkat 9 dari bawah atau urutan ke-71 pada 2018. Siswa belum bisa melakukan analisis konsep IPA untuk dihubungkan dengan kehidupan sehari-hari.

Literasi sains merupakan kemampuan untuk memahami masalah yang berhubungan 
dengan sains dan mengaplikasikanya bagi kebutuhan masyarakat (OECD, 2016). Menurut C.E.deBoer dalam Toharudin (2011), mengatakan bahwa istilah "Scientific Literacy" atau diartikan yaitu literasi sains pertama kali dikemukakan adalah Paul de Hart Hurt dari Stamford University yang menyatakan bahwa Scientific Literacy adalah pemahaman sains dan bagaimana mengaplikasikan untuk kebutuhan masyarakat. Literasi sains beririsan dengan keterampilan hidup, yang berarti bahwa literasi sains tidak hanya ditekankan pada bidang sains tetapi juga dalam konteks sosial untuk semua orang.

Literasi sains merupakan kemampuan dasar yang harus dimiliki oleh manusia berupa kemampuan organisasi, analisis, serta menginterpretasikan fenomena yang didapatkan dengan baik (Widayoko et al., 2018). Siswa yang memiliki literasi sains baik akan mampu menghubungkan antara sains, teknologi, dan masyarakat. Siswa juga memiliki sikap peka terhadap lingkungan. Kemampuan literasi yang baik juga akan membuat siswa mampu menganalisis berbagai fenomena di sekitar secara ilmiah dengan pengetahuan sains (Braaten \& Windschitl, 2011; Seah, 2016).

Literasi sains siswa rendah dikarenakan salah satunya yaitu penggunaan metode pembelajaran dan buku ajar yang kurang sesuai. Guru lebih banyak melakukan pembelajaran hanya dengan patokan Buku Pendamping Siswa (BSE) yang tersedia sehingga siswa cenderung tidak mengeksplore dan memaksimalkan kemampuan yang dimiliki (Fuadi et al., 2020; Kristyowati \& Purwanto, 2019).

Pembelajaran perlu banyak inovasi untuk bisa meningkatkan berbagai kemampuan tersebut disertai dengan kecakapan penggunaan media berbasis digital dan teknologi. Jadi, penelitian ini bertujuan untuk studi analisis pengembangan e-modul berbasis inkuiri terbimbing dengan memanfaatkan sumber belajar potensi lokal untuk meningkatkan literasi sains siswa.

\section{Metode Penelitian}

Penelitian ini masuk ke
penelitian dan pengembangan atau
(Research and Development).

pengembangan yang digunakan adalah model pengembangan ADDIE yang terdiri dari lima tahap: (1) Analysis, (2) Design, Development, (4) Implementation, dan (5) Evaluation (Branch, 2009). Penelitian ini merupakan tahap pertama dari model pengembangan ADDIE yaitu analisis kebutuhan e-modul IPA berbasis inkuiri terbimbing yang memanfaatkan potensi lokal untuk meningkatkan literasi sains. Penelitian ini dilaksanakan di Kabupaten Ponorogo. Subjek penelitian adalah guru IPA dan siswa SMP/MTs sederajat. Pengumpulan data melalui penyebaran link kuesioner google form dengan data kuantitatif. Kuesioner penelitian bersifat tertutup.

\section{Hasil Penelitian dan Pembahasan}

Hasil penelitian ini diperoleh dari pengisian angket berupa link google form yang diisi secara online dengan total responden beberapa guru dan siswa di beberapa sekolah yang berada di Kabupaten Ponorogo. Total responden adalah sebanyak 101 responden yang terdiri dari siswa dan beberapa guru. Kuesioner yang disebarkan online melalui google form dimaksudkan untuk mempercepat dan memudahkan pengisian.

Hasil analisis kebutuhan guru dan siswa terhadap e-modul berbasis inkuiri terbimbing yang memanfaatkan potensi lokal wilayah antara lain:

Kegiatan pembelajaran yang dilaksanakan sekolah merupakan berbasis daring (dalam jaringan) dan juga luring (luar jaringan). Kegiatan pembelajaran daring dapat disebut juga pembelajaran jarak jauh. Sebanyak $86,87 \%$ mengatakan pembelajaran dilakukan jarak jauh. Berikut diagram kegiatan pembelajaran siswa. 


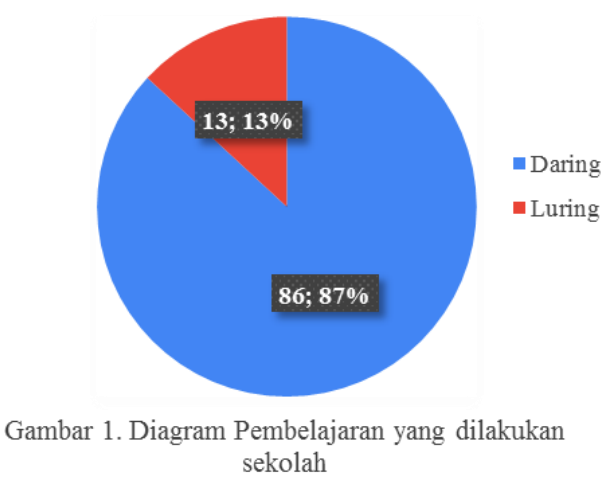

Banyak siswa dan guru yang kesulitan saat melaksanakan pembelajaran secara jarak jauh. Hal tersebut dikarenakan oleh beberapa faktor yaitu belum maksimalnya dunia pendidikan dalam memanfaatkan teknologi selama ini. Sehingga pembelajaran yang dilakukan guru hanya melalui tugas-tugas dan materi yang kemudian dikirim melalui platform seperti whatapp atau google classroom. Tidak ada aktivitas belajar yang membuat siswa aktif sehingga siswa tidak memahami apa yang ia pelajari.

Guru sudah sering melakukan kegiatan pembelajaran yang disarankan oleh kurikulum 2013, terutama inkuiri terbimbing. Tetapi karena pembelajaran sekarang lebih banyak dilakukan secara jarak jauh, kegiatan pembelajaran menjadi kurang efektif. Kegiatan pembelajaran lebih banyak diintruksikan untuk mengerjakan tugas-tugas yang ada di buku dan kemudian diunggah. Hal tersebut bertentangan dengan aktivitas inkuiri. Pembelajaran inkuiri mengajarkan siswa memanfaatkan ilmu sains dengan melakukan observasi untuk mendapatkan solusi dari berbagai permasalahan yang berkaitan dengan fenomena-fenomena nyata. Siswa saling bertukar informasi, melakukan diskusi, dan mengomunikasikan apa yang didapatkan melalui tulisan ataupun lisan (Hapgood \& Palincsar, 2006). Berikut Sintaks pembelajaran inkuiri terbimbing menurut Llewellyn (2013): (1) Eksplorasi fenomena; (2) Memfokuskan pertanyaan; (3) Merencanakan investigasi;(4) Melaksanakan investigasi; (5) Menganalisis data_dan hasil;_(6) Menyusun pengetahuan baru; dan (7) Mengomunikasikan.

Model inkuiri mengutamakan proses penyelidikan dalam memperoleh jawaban dari sebuah pertanyaan. Proses penyelidikan yang dilakukan didasari oleh pencarian dan penemuan yang dilakukan secara sistematis. Pembelajaran inkuiri membuat siswa memiliki pengalaman belajar secara langsung sehingga terjadi proses pendekatan ilmiah (Lee, 2011). Pembelajaran berbasis inkuiri terbimbing yang berperan sebagai pembimbing adalah guru. Guru sebagai fasilitator yang memandu dan mengarahkan saat proses pembelajaran berlangsung. Guru membimbing siswa dalam memilih variabel, merencanakan observasi, langkah-langkah observasi hingga menemukan solusi. Pada inkuiri terbimbing guru harus terlebih dahulu merumuskan masalah (Lee, 2011). Guru tidak melepas siswa begitu saja untuk menyelesaikan permasalahan tetapi guru tetap membimbing dan mengarahkan siswa ketika siswa kesulitan mengikuti pembelajaran.

Pembelajaran inkuiri terbimbing memiliki beberapa kelebihan. Guru membimbing siswa saat proses pembelajaran sehingga siswa yang kesulitan tetap bisa mengikuti pembelajaran. Menurut Ambarsari et al. (2013), model pembelajaran inkuiri terbimbing memiliki beberapa kelebihan, antara lain:

1. Siswa memiliki ruang penuh untuk membangun berbagai aspek baik kognitif, afektif, ataupun psikomotor

2. Siswa memiliki kesempatan untuk melakukan eksperimen dalam menyelesaikan permasalahan sehingga menumbuhkan motivasi belajarnya

3. Siswa melibatkan diri aktif dalam pembelajaran sehingga dapat melakukan pembelajaran bermakna

4. Siswa dapat meminta arahan dan bimbingan guru saat mengalami kesulitan

Guru mengatakan belum pernah melaksanakan tes yang mengukur kemampuan literasi sains siswa, sehingga kemampuan literasi siswa belum dapat diketahui. Berdasarkan penelitian yang dilakukan Naturasari et al., (2017) mengatakan bahwa kemampuan literasi sains siswa se-kabupaten Pati tergolong rendah dengan persentase sebesar 55\%, sedang $45 \%$ dan tinggi $0 \%$. Penelitian yang dilakukan Sutrisna (2021) dengan hasil kemampuan literasi sains siswa di kota Sungai Penuh tergolong rendah karena hanya bernilai rata-rata 31,58. Data lain rendahnya kemampuan literasi sains 
dibuktikan oleh penelitian yang dilakukan Andriani et al. (2018), di beberapa SMP di Sumatera Selatan menggunakan kerangka PISA dan diperoleh hasil kemampuan literasi sains siswa masih sangat rendah.

Faktor-faktor literasi sains siswa rendah antara lain dipengaruhi oleh pembelajaran yang belum memfasilitasi pengembangan kemampuan literasi sains siswa. Soal-soal yang biasa diberikan guru juga terlalu mudah sehingga siswa kesulitan saat mengerjakan soal menggunakan wacana (Sutrisna, 2021). Padahal, tujuan utama pembelajaran IPA yaitu ketercapaian literasi sains (Wenning, 2007).

Berikut indikator literasi sains menurut Gormally et al. (2015) yaitu: (1) melakukan identifikasi pendapat ilmiah secara valid; (2) menelusuri berbagai literatur yang efektif; (3) menganalisis berbagai desain penelitian dan dampaknya terhadap temuan/kesimpulan; (4) mengubah data menjadi bentuk grafik secara tepat; (5) memecahkan masalah menggunakan keterampilan kuantitatif, termasuk statistik dasar; (6) memahami dan menginterpretasikan statistik dasar; (7) melakukan inferensi, prediksi, dan penarikan kesimpulan berdasarkan data kuantitatif.

Pembelajaran memerlukan inovasi agar bisa meningkatkan berbagai kemampuan terutama literasi_sains yang seiring dengan kemajuan bidang teknologi. Pembelajaran harus memfasilitasi siswa untuk melakukan pembelajaran mandiri dengan jarak jauh, maka dari itu bahan ajar dibutuhkan untuk memfasilitasi proses belajar sesuai kemampuan siswa secara mandiri.

Literasi sains siswa dapat membuat siswa belajar dengan terus menerus juga dapat hidup bermasyarakat yang sejalan dengan perkembangan ilmu pengetahuan dan teknologi. Siswa juga diharap mampu mempunyai rasa peka terhadap isu-isu global terutama berkaitan dengan lingkungan. Hal tersebut dikarenakan is-isu terkait lingkungan saat ini banyak dibicarakan. Banyak kegiatan seperti eksploitasi lahan, pencemaran limbah, penebangan pohon, penangkapan satwa dilindungi dll. Melalui kemampuan literasi sains yang dimiliki, siswa diharap bisa menyelesaikan permasalahan-permasalahan tersebut (Pratiwi et al., 2019; Yuliati, 2017).
Pembelajaran jarak jauh dilaksanakan guru menggunakan beberapa platform antara lain yaitu: zoom, google meet, whatshapp, google classroom, google site, dan e-learning. Persentase terbanyak yang digunakan guru yaitu pembelajaran menggunakan whatsapp dan google classroom. Dalam pembelajaran, sebanyak 91\% siswa menyatakan guru menggunakan bahan ajar elektronik. Berikut diagram penggunaan bahan ajar elektronik saat pembelajaran.

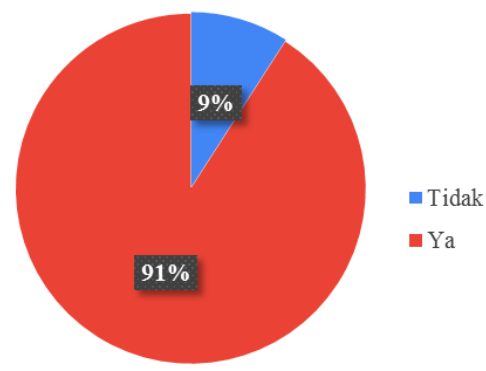
Gambar 2. Diagram Penggunaan Bahan Ajar
Elektronik saat Pembelajaran

Bahan ajar yang digunakan guru saat pembelajaran terbagi dalam bentuk ppt, video pembelajaran, gambar-gambar, buku teks, dan juga e-modul atau materi pdf. Penggunaan bahan ajar elektronik pembelajaran terbanyak yaitu video dengan persentase $66,7 \%$. Berikut diagram penggunaan bahan ajar dalam pembelajaran.

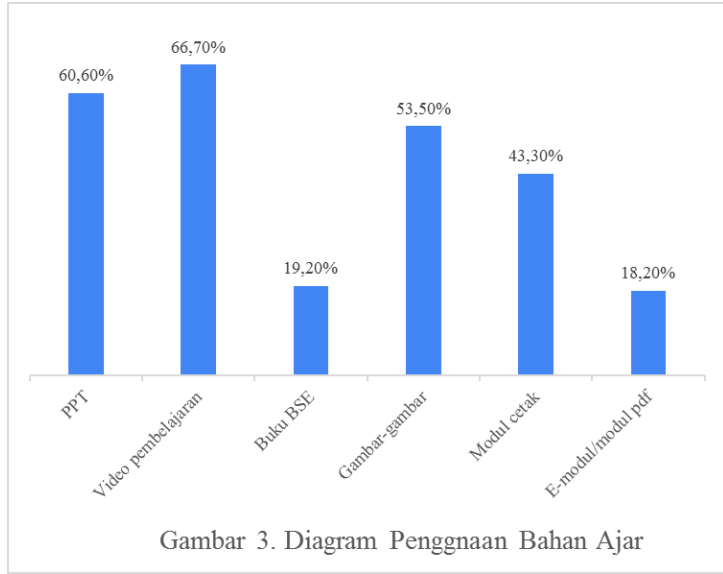

Bahan ajar elektronik sudah biasa digunakan guru dalam proses pembelajaran. Bahan ajar biasanya didapatkan guru melalui download dari internet/youtube. Guru 
kesulitan apabila membuat bahan ajar sendiri. Guru mengatakan pernah menggunakan bahan ajar berupa e-modul. E-modul yang digunakan guru didapatkan dari kemendikbud. Guru belum pernah merancang e-modul sendiri yang disesuaikan dengan kondisi siswa di sekolah.

E-modul merupakan salah satu bahan ajar yang_menarik, dapat memuat animasi, video, dan audio. E-modul dapat digunakan untuk memfasilitasi pembelajaran IPA bagi siswa dengan sumber belajar yang sudah biasa diketahui. Melalui e-modul, contoh fakta atau fenomena yang sesuai dengan lingkungan sekitarnya dapat disajikan bagi siswa. Lingkungan sekitar yang potensial dapat digunakan untuk penyajian fenomena atau pengamatan terhadap lingkungan untuk menemuka solusi dari berbagai masalah (Dedy et al., 2016; Laili et al., 2019).

Kelebihan e-modul menurut Kemendikbud (2017), antara lain yaitu: (1) membuat siswa lebih termotivasi untuk melakukan pembelajaran karena berisi video, animasi, dll yang tidak tersedia dalam modul cetak; (2) memudahkan proses evaluasi bagi siswa dan guru; (3) dapat disusun sesuai materi yang ada pada tiap semester; (4) Pembelajaran lebih efektif; (5) lebih interaktif dan dinamis; dan (6) penyajian lebih dikonversikan menjadi bentuk visual.

Sebelum melakukan pengembangan emodul maka harus memperhatikan beberapa petunjuk pengembangan seperti: e-modul baiknya bisa menumbuhkan minat belajar siswa, mudah digunakan siswa, dilengkapi tujuan pembelajaran yang harus tercapai, didasarkan pada fleksibilitas belajar, bahasa yang digunakan komunikatif dan interaktif, dan dilengkapi dengan petunjuk penggunaan (Kemendikbud, 2017). Jadi, dalam pengembangan e-modul perlu diperhatikan konten yang disajikan sehingga tujuan pembelajaran dapat tercapai, materi dapat tersampaikan dengan baik, dan memfasilitasi siswa untuk belajar secara mandiri sesuai dengan kemampuan masing-masing.

Penyusunan e-modul hendaknya memberi peluang kepada siswa agar dapat mengembangkan beberapa keterampilan yaitu keterampilan proses, kemampuan inkuiri, kemampuan berpikir, dan kemampuan literasi sains. E-Modul sebagai bahan ajar sudah selayaknya mampu memfasilitasi kemampuan literasi sains siswa sebagai bagian dari proses inkuiri untuk menemukan konsep-konsep ataupun prinsip-prinsip IPA berdasarkan fenomena IPA yang ada di lapangan.

Pembelajaran IPA dilaksanakan untuk menganalisis lingkungan, kondisi alam di sekitar, dan mengetahui berbagai potensi alam nusantara sehingga kearifan /potensi lokal daerah dapat digunakan sebagai sumber belajar (Permendikbud, 2016). Kearifan/potensi lokal dapat dipadukan untuk kegiatan dalam pendidikan melalui sumber belajar. Sumber belajar mengandung pesan materi atau yang lain yang dimaksudkan agar pembelajaran yang dilakukan guru berhasil (Abdullah, 2012).

Penentuan/pemilihan potensi lokal suatu wilayah dilakukan melalui identifikasi tingkat relevansi potensi tersebut dengan Kompetensi yang ada dalam pembelajaran IPA, baik kompetensi inti atapun kompetensi dasar. Selain itu, harus memperhatikan kelayakan potensi tersebut untuk diimplementasikan dalam pembelajaran berupa dana, alat dan bahan yang diperlukan, sumber daya yang tersedia, keterlaksanaan, dan capaian yang didapatkan (Sunariyati et al., 2017).

Guru pernah memanfaatkan lingkungan sekitar rumah dan sekolah siswa, misalnya kebun sekolah. Tetapi belum pernah memanfaatkan potensi lokal wilayah untuk digunakan sebagai Sumber belajar. Pemanfaatan tersebut dimaksudkan agar siswa melestarikan berbagai sumber daya potensial agar tidak hilang di kemudian hari.

Salah satu potensi wilayah Kabupaten Ponorogo yang dapat dimanfaatkan sebagai sumber belajar adalah Telaga Ngebel yang masih terjaga kelestariannya. Siswa akan mendapatkan pengetahuan secara langsung dalam mempelajari materi terkait makhluk hidup dan lingkungannya melalui Telaga Ngebel. Telaga Ngebel merupakan objek wisata yang biasa dikunjungi oleh warga Ponorogo dan sekitarnya. Berikut diagram persentase siswa yang pernah berkunjung ke Telaga Ngebel. 


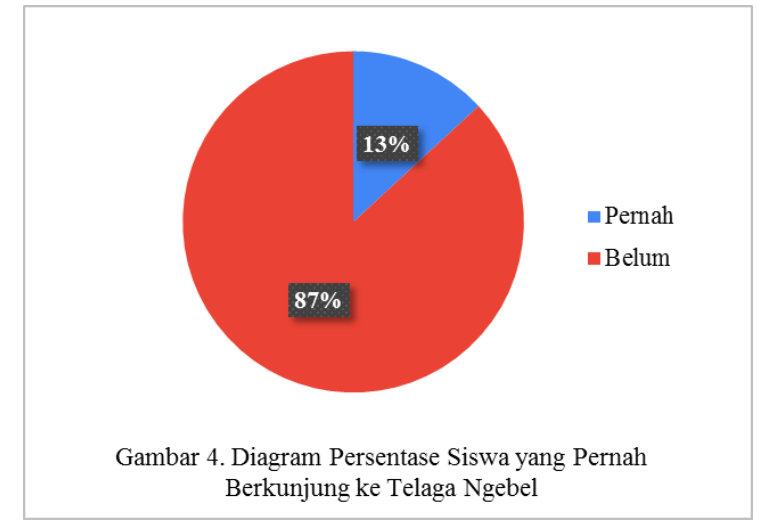

Sebanyak $87 \%$ siswa pernah berkunjung ke Telaga Ngebel sehingga mereka sudah familiar dengan kondisi flora fauna dan lingkungan sekitarnya. Setiap siswa tentunya menginginkan sumber belajar yang lengkap dan menarik. Maka potensi lokal wilayah yang sudah biasa siswa ketahui merupakan salah satu solusi untuk digunakan sebagai sumber belajar IPA (Dwipayana et al., 2020).

Potensi lokal dapat dimanfaatkan sebagai sumber belajar yang disesuaikan dengan kebutuhan dan kegiatan belajar siswa. Pemanfaatan potensi lokal akan berpengaruh pada capaian tujuan pembelajaran. Kegiatan pembelajaran menggunakan sumber belajar lingkungan sekitar akan lebih efektif dibandingkan menggunakan buku ajar. Guru baiknya lebih memperhatikan potensi lokal yang ada untuk dihubungkan dengan konsepkonsep dalam pembelajaran IPA agar pembelajaran siswa lebih bermakna (Lepiyanto \& Pratiwi, 2015; Sumarni et al., 2016).

Sumber belajar merupakan segala sesuatu yang ada di lingkungan sekitar baik makhluk hidup atau benda yang bisa dimanfaatkan nuk memudahkan siswa dan guru dalam proses pembelajaran. Sumber belajar digunakan untuk memperoleh pengalaman dan keterampilan dalam mencapai tujuan pembelajaran yang sesuai harapan (Susilo, 2018).

Sumber belajar harus disesuaikan dengan kebutuhan, daya guna, dan efektivitas saat digunakan (Abdullah, 2012). Ada beberapa kriteria dalam memilih sumber belajar menurut Glover et al. dalam Abdullah (2012), antara lain: (1) sumber belajar disesuaikan dengan tujuan atau capaian dalam $\mathrm{KD}$, disesuaikan dengan tujuan pembelajaran yang telah ditentukan baik dalam aspek kognitif, afektif ataupun psikomotor; (2) sumber belajar harus disesuaikan dengan isi pembelajaran yang tepat, baik fakta, konsep, prinsip. Pada intinya sumber belajar harus dapat membantu kegiatan belajar yang efektif sesuai dengan kebutuhan belajar dan kemampuan siswa; (3) Sumber belajar harus berdaya guna, fleksibel, dan bertahan lama karena harus dapat digunakan kapan saja; dan (4) Mudah digunakan oleh siswa.

Andriana et al., (2017) pernah mengembangkan multimedia pembelajaran IPA yang memanfaatkan kearifan lokal di SD dengan hasil multimedia pembelajaran menggunakan kearifan lokal Baduy mampu membangun hasrat dan rasa ingin tahu siswa. Siswa merasa senang karena hal tersebut merupakan hal baru dalam kegiatan belajar mereka. Selain hal tersebut, siswa juga memiliki keinginan untuk berhasil dalam evaluasi pembelajaran. Penelitian lain terkait pemanfaatan kearifan/potensi lokal untuk sumber belajar dilakukan oleh (Hasbiyati, 2015) yaitu pemanfaatan limbah tahu sebagai sumber belajar untuk materi pengelolaan lingkungan. Penelitian (Elmovriani et al., 2016) memanfaatkan keanekaragaman kupukupu yang ada di wana wisata penggarong untuk sumber belajar materi keanekaragaman hayati. Penelitian (Lidi et al., 2021) memanfaatkan potensi lokal Tambi Uma (mencangkul kebun) Suku Ende sebagai sumber belajar biologi. Penelitian (Sunariyati et al., 2017) memanfaatkan potensi lokal hutan rawa gambut dan hutan kerangas Kabupaten Gunung Mas untuk digunakan sebagai kegiatan praktikum berbasis etnobiologi.

Pemanfaatan sumber belajar menggunakan potensi lokal diawali dengan eksplorasi lingkungan sekitar yang disesuaikan dengan kurikulum yang berlaku (Susilo, 2018). Sumber belajar yang diperoleh dari potensi lokal membantu guru menanamkan nilai-nilai karakter karena terpaku pada lingkungan siswa. Sumber belajar potensi lokal merupakan sumber belajar yang kontekstual dan inovatif. Oleh karena itu potensi lokal harus diperhatikan guru untuk dikembangkan menjadi sumber belajar karena banyak bermanfaat untuk siswa dan juga untuk perkembangan dan pelestarian selanjutnya dari potensi lokal itu sendiri (Lidi et al., 2021). 
Menurut Prastowo (2014), sumber belajar menurut bentuknya dikelompokkan menjadi 5 macam, antara lain: (1) Tempat/lingkungan alam, misalnya lingkungan sekolah/rumah, museum, cagar alam, gunung, hutan atau tempat yang dijadikan tempat bagi siswa untuk kegiatan pembelajaran; (2) Benda, misalnya situs peninggalan, candi, keris atau segala sesuatu yang dapat menjadikan perubahan perilaku siswa; (3) Orang, misalnya polisi, guru, pemangku adat, ilmuan, politisi, atau seseorang yang ahli dalam bidang tertentu yang dapat dijadikan pembelajaran bagi siswa; (4) Buku, segala jenis buku pelajaran merupakan sumber belajar bagi siswa; (5) Peristiwa atau fakta, misalnya bencana alam, wabah penyakit, peperangan, dll.

Pemanfaatan potensi lokal akan mempermudah siswa dalam pemahaman konsep IPA. Hal tersebut dikarenakan siswa belajar secara langsung dari pengalaman kehidupan sehari-hari sehingga motivasi siswa menjadi tinggi dalam kegiatan pembelajaran. Dengan motivasi belajar tinggi siswa akan senang dan memahami konsep-konsep materi (Lidi et al., 2021)

Guru dapat menganalisis potensi lokal di daerah masing-masing untuk dijadikan sebagai sumber belajar. Sumber belajar yang potensial tersebut dapat buat dalam bentuk bahan ajar e-modul yang_efektif digunakan dalam kondisi pembelajaran jarak jauh ataupun tatap muka. Penyusunan e-modul harus disesuaikan dengan tujuan dan indikator pembelajaran. Berikut diagram respons pengembangan e-modul berbasis inkuiri terbimbing yang memanfaatkan potensi lokal untuk meningkatkan literasi sains siswa.

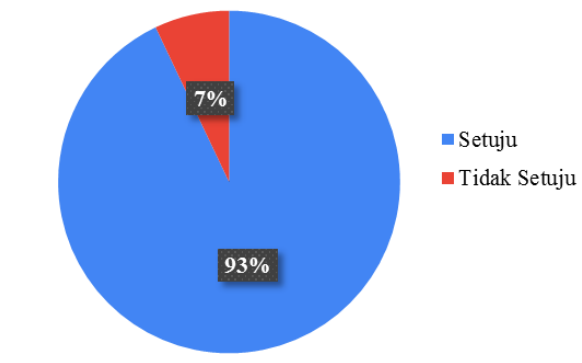

Gambar 4. Diagram Respons Pengembangan Emodul
Sebanyak 93\% menyatakan perlu dan setuju apabila dilakukan pengembangan modul elektronik (e-modul) untuk menunjang pembelajaran. Pemanfaatan e-modul yang berbasis inkuiri terbimbing dapat menolong siswa dalam pemahaman materi yang diajarkan terutama meningkatkan literasi sains siswa. Proses peningkatan literasi sains dilakukan dengan pembiasaan siswa melakukan identifikasi ilmiah, menelusuri literatur, melakukan eksperimen, mengolah dan memahami data yang didapatkan, dan menarik kesimpulan sehingga menemukan solusi dari permasalahan (Gormally et al., 2015). Siswa bisa melakukan kegiatan pembelajaran sesuai kemampuan masingmasing dan guru hanya sebagai pembimbing apabila siswa melakukan kesulitan. Pembelajaran inkuiri terbimbing cenderung menyenangkan dan bermanfaat bagi siswa sehingga dapat meningkatkan literasi sains serta dapat meningkatkan hasil belajarnya (Wen et al., 2020). Melalui pembelajaran inkuiri pemahaman siswa dapat meningkat dan pembelajaran lebih bermakna (Wenning, 2007).

Pendidikan harus ikut serta dalam pengembangan di bidang IPTEK. Oleh karena itu dibutuhkan banyak inovasi yang memiliki dasar pemikiran ilmiah sehingga tumbuhlah manusia yang memiliki kemampuan literasi sains untuk memenuhi tantangan era society 5.0 .

\section{Kesimpulan dan Rekomendasi}

Berdasarkan penelitian yang telah dilakukan dapat disimpulkan bahwa hasil studi analisis kebutuhan bahwa diperlukan pengembangan e-modul IPA berbasis inkuiri terbimbing dengan sumber belajar potensi lokal terhadap kemampuan literasi sains. Sebanyak 93\% menyatakan perlu dan setuju apabila dilakukan pengembangan modul elektronik (e-modul) untuk menunjang pembelajaran. Pengembangan e-modul diharapkan dapat mempermudah siswa paham terhdap materi pembelajaran juga dapat menumbuhkan atau bahkan meningkatkan kemampuan literasi sains siswa.

Berdasarkan kesimpulan yang telah diuraikan di atas, peneliti merekomendasikan 
agar produk tersebut dapat dikembangkan dan digunakan dalam kegiatan pembelajaran IPA.

\section{Daftar Pustaka}

Abdullah, R. (2012). Pembelajaran Berbasis Pemanfaatan Sumber Belajar. Jurnal Ilmiah Didaktika, 12(2), 216-231.

Ambarsari, W., Slamet, S., \& Maridi. (2013). Penerapan Pembelajaran Inkuiri Terbimbing terhadap Keterampilan Proses Sains Dasar pada Pelajaran Biologi Siswa Kelas VIII SMP Negeri 7 Surakarta. Jurnal Pendidikan Biologi, 5(1), 81-95.

Andriana, E., Vitasari, M., Oktarisa, Y., \& Novitasari, D. (2017). Pengembangan Multimedia Pembelajaran IPA Berbasis Kearifan Lokal di Sekolah Dasar. Jurnal Pendidikan Sekolah Dasar, 3(2), 186-200.

Andriani, N., Saparini, S., \& Akhsan, H. (2018). Kemampuan Literasi Sains Fisika Siswa SMP Kelas VII Di Sumatera Selatan Menggunakan Kerangka PISA (Program for International Student Assesment). Berkala Ilmiah Pendidikan Fisika, 6(3), 278-291.

Anggareni, N. W., Ristiati, N. P., \& Widiyanti, N. L. P. M. (2013). Implementasi Strategi Pembelajaran Inkuiri Terhadap Kemampuan Berpikir Kritis dan Pemahaman Konsep IPA siswa SMP. 3.

Braaten, M., \& Windschitl, M. (2011). Working toward a stronger conceptualization of scientific explanation for science education. Science Education, 95(4), 639-669.

Branch, M. R. (2009). Instructional Design: The ADDIE Approach. USA: University of Georgia.

Dedy, H., Ibrohim, \& Sri, R. (2016). Pengaruh Model Pembelajaran Inkuiri Terbimbing Berbasis Lingkungan Terhadap Keterampilan Proses dan Penguasaan konsep IPA. Jurnal Pendidikan, 1(8), 1567-1574.

Dwipayana, P. A. P., Redhana, I. W., \& Juniartina, P. P. (2020). Analisis Kebutuhan Pengembangan Multimedia Interaktif Berbasis Konteks Budaya Lokal Untuk Pembelajaran IPA SMP. Jurnal Pendidikan Dan Pembelajaran Sains Indonesia, 3(1), 49-60.

Elmovriani, D., Prasetyo, A. P. B., \& Ridhlo, S.
(2016). Keanekaragaman Jenis Kupu-Kupu di Wana Wisata Penggaron sebagai Bahan Penyusun Modul Pembelajaran Biologi. Journal of Innovative Science Education, $5(1), 45-53$.

Fa'idah, R. N., Koes H, S., \& Mahanal, S. (2019). Pengaruh Model Pembelajaran Inkuiri Terbimbing terhadap Literasi Sains Siswa Kelas V SD. Jurnal Pendidikan: Teori, Penelitian, Dan Pengembangan, 4(12), 1704-1708.

Fuadi, H., Robbia, A. Z., Jamaluddin, J., \& Jufri, A. W. (2020). Analisis Faktor Penyebab Rendahnya Kemampuan Literasi Sains Peserta Didik. Jurnal Ilmiah Profesi Pendidikan, 5(2), 108-116.

Gormally, C., Brickman, P., Hallar, B., \& Armstrong, N. (2015). Effects of Inquirybased Learning on Students' Science Literacy Skills and Confidence. International Journal for the Scholarship of Teaching and Learning, 3(2), 32-43.

Hapgood, S., \& Palincsar, A. S. (2006). Where literacy and science intersect. Educational Leadership, 64(4), 56-60.

Hasbiyati, H. (2015). Pemanfaatan Limbah Tahu sebagai Potensi Sumber Belajar IPA pada materi Pengelolaan Lingkungan. Bioshell, 4(1), 257-267.

Kemendikbud. (2017). Panduan Praktis Penyusun e-Modul Pembelajaran. Direktorat Jenderal Pendidikan Dasar dan Menengah.

Kristyowati, R., \& Purwanto, A. (2019). Pembelajaran Literasi Sains Melalui Pemanfaatan Lingkungan. Scholaria: Jurnal Pendidikan Dan Kebudayaan, 9(2), 183-191.

Laili, I., Ganefri, \& Usmeldi. (2019). Efektivitas Pengembangan E-Modul Project Based Learning Pada Mata Pelajaran Instalasi. Jurnal Imiah Pendidikan Dan Pembelajaran, 3(3), 306-315.

Lee, V. S. (2011). The Power of Inquiry as a Way of Learning. Innovative Higher Education, 36(3), 149-160.

Lepiyanto, A., \& Pratiwi, D. (2015). Pengembangan bahan ajar berbasis inkuiri terintegrasi nilai karakter peduli lingkungan pada materi ekosistem. Bioedukasi, 6(2), 143-147. 
Lidi, M. W., Daud, M. H., \& Bolong, M. Y. M. (2021). Jurnal Pendidikan Biologi. Jurnal Pendidikan Biologi, 12(1), 45-51.

Llewellyn, D. (2013). Teaching High School Science Through Inquiry and Argumentation. USA: Corwin Press, INC.

Nastiti, F. E., \& 'Abdu, A. R. N. (2020). Kesiapan Pendidikan Indonesia Menghadapi era society 5.0. Edcomtec: Jurnal Kajian Teknologi Pendidikan, 5(1), 61-66.

Naturasari, H., Roshayanti, F., \& Nurwahyunani, A. (2017). Profil Kualitas Literasi Sains Siswa SMP Se-Kabupaten Pati. Bioma: Jurnal Ilmiah Biologi, 5(2).

OECD. (2016). Assessment and Analytical Framework Science, Reading, Mathematic, Financial Literacy and Collaborative Problem Solving. Paris: OECD Publishing.

Peraturan Menteri Pendidikan dan Kebudayaan Republik Indonesia Nomor 22 Tahun 2016 tentang Standar Isi, Standar Proses, dan Standar Penilaian Pendidikan Dasar dan Menengah. BSNP Indonesia (online), (http://bsnpindonesia.org) diakses Agustus 2021.

Prastowo, A. (2014). Panduan Kreatif Membuat Bahan Ajar Inovatif. Diva Press.

Pratiwi, S. N., Cari, C., \& Aminah, N. S. (2019). Pembelajaran IPA Abad 21 dengan Literasi Sains Siswa. Jurnal Materi Dan Pembelajaran Fisika (JMPF), 9(1), 34-42.

Program for International Assessment of Student (PISA). Result from PISA 2018 (Online), (http://oecd.org/pisa/publication/PISA2018) diakses Agustus 2021.

Rusilowati, A., Kurniawati, L., Nugroho, S. E., \& Widiyatmoko, A. (2016). Developing an instrument of scientific literacy asessment on the cycle theme. International Journal of Environmental and Science Education, 11(12), 5718-5727.

Seah, L. H. (2016). Understanding the Conceptual and Language Challenges Encountered by Grade 4 Students When Writing Scientific Explanations. Research in Science Education, 46(3), 413-437.

Sumarni, W., Sudarmin, Wiyanto, \& Supartono. (2016). The reconstruction of society indigenous science into scientific knowledge in the production process of palm sugar. Journal of Turkish Science Education, 13(4), 281-292.

Sunariyati, S., Suatma, \& Miranda, Y. (2017). Pengembangan Praktikum Biologi di Sekolah Menengah Berbasis Etnobiologi. Neuropsychology, 3(8), 85-102.

Susilo, M. J. (2018). Analisis Potensi Lingkungan Sekitar sebagai Sumber Belajar Biologi yang Berdayaguna. Procending Biology Education Conference, 15(1), 541-546.

Sutrisna, N. (2021). Analisis Kemampuan Literasi Sains Peserta Didik SMA di Kota Sungai Penuh. Jurnal Inovasi Penelitianitian, 1(12), 2683-2694.

Toharudin, U. (2011). Membangun Literasi Sains Peserta Didik. Bandung: Humaniora.

Tursinawati. (2016). Penguasaan Konsep Hakikat Sains dalam Pelaksanaan Percobaan pada Pembelajaran IPA di SDN Kota Banda Aceh. Jurnal Pesona Dasar, 2(4), 72-84.

Wen, C. T., Liu, C. C., Chang, H. Y., Chang, C. J., Chang, M. H., Fan Chiang, S. H., Yang, C. W., \& Hwang, F. K. (2020). Students' guided inquiry with simulation and its relation to school science achievement and scientific literacy. Computers and Education, 149.

Wenning, C. J. (2007). Assessing inquiry skills as a component of scientific literacy. Journal of Physics Teacher Education Online, 4(2), 2124.

Widayoko, A., Latifah, E., \& Yuliati, L. (2018). Peningkatan Kompetensi Literasi Saintifik Siswa SMA dengan Bahan Ajar Terintegrasi STEM pada Materi Impuls dan Momentum. Jurnal Pendidikan: Teori, Penelitian, Dan Pengembangan, 3(11), 1463-1467.

Yuliati, Y. (2017). Literasi Sains Dalam Pembelajaran Ipa. Jurnal Cakrawala Pendas, $3(2), 21-28$. 